\title{
Multi-Step Process for Selecting Strategic Sourcing Options when Designing Supply Chains
}

\author{
Imma Ribas ${ }^{1}$ (D) , Amaia Lusa² ${ }^{2}$, Albert Corominas ${ }^{2}$ (iD \\ ${ }^{1}$ Department of Management / TechTalent-Lab, Universitat Politècnica de Catalunya (Spain) \\ ${ }^{2}$ Department of Management / ETSEIB/IOC Universitat Politècnica de Catalunya (Spain) \\ imma.ribas@upc.edu,Amaia.lusa@upc.edu,albert.corominas@upc.edu
}

Received: November 2020

Accepted: March 2021

\section{Abstract:}

Purpose: This paper, dedicated to the selection of strategic sourcing options as a part of the supply chain design, aims to provide supply chain designers with guidelines for selecting the best strategic sourcing option for each item (i.e., products, modules, parts and services).

Design/methodology/approach: The study is based on a literature review of the sourcing options, buyer-supplier relationships, factors and criteria for selecting a sourcing strategy and the authors' personal experience in this field.

Findings: We propose a multi-step process by considering the three dimensions of the strategic sourcing options (i.e., who and how many will make the item; in cases of outsourcing, the kind of relationship between buyer and supplier(s); and where the item is to be made) along with the characteristics of the context, demand and product, and the relevant criteria to evaluate them.

Originality/value: The main contributions are: the consideration of three dimensions to characterise the strategic sourcing options; a review of the factors and criteria relevant to decision-making in this respect for each item (i.e., products, modules, parts and services); and the guidelines provided for each step of the process.

Keywords: strategic sourcing, supply chain design, procurement and production network, outsourcing

\section{To cite this article:}

Ribas, I., Lusa, A., \& Corominas, A. (2021). Multi-step process for selecting strategic sourcing options when designing supply chains. Journal of Industrial Engineering and Management, 14(3), 477-495. https://doi.org/10.3926/jiem.3391

\section{Introduction}

Decisions about strategic sourcing options configure the structure of the procurement and production network, one of the main components of a supply chain. The importance of this set of decisions is illustrated in Giunipero, Bittner, Shanks and Cho (2019) where, in spite of using restricting inclusion criteria the authors reviewed 520 papers, all published in the last twenty-three years in twenty journals ranked in the JCR in 2016 with an impact factor higher than 2.0 . 
In supply chains, procurement and production must necessarily be considered together, because there is usually the option of making or buying each item that makes up the final product. This paper, dedicated to the selection of strategic sourcing options as a part of the supply chain design, aims to provide supply chain designers with guidelines for selecting the best strategic sourcing option for each item (i.e., products, modules, parts and services).

The problem is addressed at the strategic level. Therefore, it is distinct from tactically and operationally selecting specific suppliers from a pre-set list and allocating orders to them. These operational and tactical decisions can change over time, while maintaining the same strategic option.

As happens in any other decision-making process, selecting a strategic sourcing option requires considering a set of feasible alternatives, as well as establishing the relevant criteria for each specific decision and the factors for evaluating the options for each criterion. This study shows that defining feasible options requires a more analytical point of view than those usually adopted in the literature, because defining an option requires specifying three characteristics (which might also be loosely called "dimensions"): (i) who and how many will make the item; (ii) in cases of outsourcing, the kind of relationship between the buyer and supplier(s); and (iii) where the item is to be made.

The multi-step process proposed in this paper considers this three-dimensional aspect of the strategic sourcing options, along with the characteristics of the context, demand and product, and the relevant criteria to evaluate them.

The rest of the paper is organised as follows. In Section 2 different options are defined for each dimension. Next, Section 3 considers the relevant criteria for each dimension. Section 4 provides the main factors considered when selecting strategic sourcing alternatives, while Section 5 presents the multi-step process to be performed when selecting a strategic sourcing option. The paper ends with the conclusions and suggestions for future lines of research.

\section{Strategic Sourcing Options}

Several papers describe sourcing options based on case studies (Dubois \& Fredriksson, 2008; Nordigården, Rehme, Brege, Chicksand \& Walker, 2014; Parmigiani \& Mitchell, 2009) by comparing sourcing alternatives (Faes \& Matthyssens, 2009; Matthyssens \& Faes, 1996; Richardson, 1993) or by providing a list of sourcing strategies (Corominas, Mateo, Ribas \& Rubio, 2015; Najafi, Lind \& Pedersen, 2014). In most of these papers, the discussion focuses on the number of suppliers (single or multiple) or on the buyer-supplier relationship, but none of the reviewed documents addresses the problem from a broader perspective. However, defining a strategic sourcing option for an item involves answering three questions: Who and how many will make the item? What is the buyer-supplier relationship? Where will the item be made? Therefore, this section starts by considering these three dimensions successively while presenting sourcing alternatives, finishing with an overview.

\subsection{First Dimension: Who and How Many Will Make the Item?}

One of the most fundamental decisions for a company concerns which items have to be produced internally and which must be outsourced. This is usually described as a binary choice between making or buying, although there is a mixed option. Choosing between these alternatives involves several decisions that must align with the company's strategy. A comprehensive literature review about making or buying can be found in Medina-Serrano, González-Ramírez and Gascó (2018).

When the company is considering whether to make an item, some questions must be answered. Is the item to be made in an existing facility or in a new one? Should a large facility be used to gain economies of scale? Or would it be better to use several smaller plants located near the markets in order to be reactive to the uncertainty of demand? All cases must consider the possibility of buying the facilities of another company in order to produce the item.

Moreover, sometimes relying on pure options for making or buying is not advisable due, for example, to risk and cost. Therefore, a company can decide to simultaneously make and buy the same item, which has been named concurrent sourcing by Parmigiani (2007), but also found in the literature as Plural sourcing or Make-and-Buy 
(Medina-Serrano, González-Ramírez, Gascó \& Llopis, 2020). Nordigården et al. (2014) analyses different mixed strategies between the two ends of a make-buy continuum, which they named parallel production: in-house dominance and outsourcing dominance. With in-house dominance, outsourcing is used to complement in-house production in order to optimise the capacity utilization of the owned plants, outsource less cost-efficient production, or as a tool for learning how to outsource. When outsourcing dominates, in-house production complements the external sourcing in order to maintain complementary competencies and avoid the risk of lock-in.

On the other hand, if the firm has decided to buy a certain item, it must decide mainly between buying from one supplier (single sourcing) or from several (multiple sourcing). The special case where a company is forced to buy from only one supplier due to exclusive rights or customer specifications is named sole sourcing (Matthyssens \& Faes, 1996; Treleven \& Bergman Schweikhart, 1988). According to Najafi et al. (2014), single sourcing can be due to the importance of the item or because few suppliers exist. Zeng (2000) asserts that companies began to move towards reducing suppliers because of the growing popularity of the just-in-time approach, which requires maintaining an excellent working relationship with suppliers to ensure that orders arrive at the right place and time and with the right quality. The authors say that establishing such a long-term relationship eliminates the need to retain other suppliers. But single sourcing has some clear disadvantages, such as over-dependency on one source, less competitive pressure on the supplier and less price competition (Matthyssens \& Faes, 1996; Zeng, 2000). To overcome these drawbacks, some companies tend to increase the number of suppliers able to supply an item (multiple sourcing). In the same vein, Heese (2015) claims that multiple sourcing might avoid dependency on a potentially complacent supplier and it introduces suppliers' competition, which might lead to improved performance and better contract terms. However, dealing with several suppliers may require longer negotiation times and may delay or disturb the buyer's production schedules (Zeng, 2000). Therefore, some bybrid alternatives are recommended in order to combine the motivations of both single and multiple sourcing and overcome these drawbacks. In this way, parallel sourcing (a term introduced by Richardson (1993)) describes the situation in which two or more suppliers with similar capabilities provide similar components. Matthyssens and Faes (1996) illustrate an example in which an automotive company producing two different car models buys each model's braking system from a different supplier. Each component is bought from a single source, but the company maintains two parallel sources as a family for braking systems. While using a single source for a component, the assembler establishes parallel sources to provide performance comparisons and competitive bidders for the next model cycle. Thus, even though the components are single-sourced, the buyer has alternative suppliers with the same abilities to deliver those components. The author argues that parallel sourcing provides the same multiple sourcing incentives for supplier performance, while allowing for reduced coordination and communications costs, which are generally benefits attributed to single sourcing. Finally, Dubois and Fredriksson (2008) analysed the triadic sourcing case of Volvo cars, in which two suppliers collaborate while also competing to take business away from each other. In this case, the buyer can invite suppliers to compete for product development assignments and/or production volume in relation to components, modules, products and platforms. Therefore, the relationship between suppliers in triadic sourcing goes a step further than the parallel sourcing option. Moreover, in parallel sourcing, suppliers compete only for production volume, whereas triadic sourcing suppliers are also invited to compete for product development assignments.

Notice that these bybrid alternatives can also be classified within the multiple sourcing group, since the differences in defining them are that they also consider the relationships between buyer and supplier as well as among suppliers. Since the buyer-supplier(s) relationship always plays an important role in defining the strategic sourcing options we consider it to be the second dimension in our framework.

Hence, the sourcing options to consider in the first dimension are: to make, to use concurrent sourcing or to buy from a single supplier (single sourcing) or multiple suppliers (multiple sourcing).

\subsection{Second Dimension: Buyer-Supplier(s) Relationship}

When buy is the chosen alternative, it is not enough to establish the number of suppliers when developing a complete strategy, as defining the type of relationship with them is also essential. For instance, one company can buy from a single supplier over a short term or establish a long-term strategic partnership. Therefore, both dimensions (number of suppliers and buyer-supplier relationship) must be considered together. 
The buyer-supplier relationship (BSR) has been studied with different approaches. Tangpong, Michalisin, Traub and Melcher (2015) classify the literature into two typologies: relation-based BSR and power-dependence BSR. The former is based on the type of exchange between buyer and supplier (type of transactions, contracts, cooperative systems, buyer-supplier relationships considering governance mechanisms, joint ventures and strategic alliances, network organization, vertical integration), whilst the latter is based on the level of partner dependence. Focusing on the power-dependence, which the buyer has to analyse when selecting new suppliers, we highlight the most important contributions. Dyer, Cho and Cgu (1998) compared the arm's-length model (minimum dependence on suppliers and maximum bargaining power) with the partnership model, and suggested segmenting the suppliers in order to allocate the correct amount of resources for managing them. They proposed classifying the relationships with suppliers into either a durable arm's-length relationship (for those that provide non-strategic inputs) and a strategic partnership (with those who supply high value items that distinguish the final product). McDonald (1999) synthesised the supplier relationships into four groups, which are an evolution from the arm's-length model to the partnership: (1) the traditional approach, an arm's-length relationship characterised by short-term orientation, a very low degree of trust and close monitoring; (2) the monitoring approach, an arm's-length relationship with close monitoring of production, logistic processes and deliveries and some help to solve problems in the production and logistic process; (3) the supplier development approach, a co-operative relationship that involves less monitoring and more sharing of information, where the buyer controls the working of the relationship; and (4) the partnership approach, a co-operative relationship with a high degree of trust and commitment, balanced power and knowledge exchange between buyers and supplier. On the other hand, Bensaou (1999) analysed US and Japanese automobile manufacturers and established four types of buyer-supplier relationships, based on the buyer's and supplier's specific investments: (1) captive buyer (high buyer investment and low supplier investment), which is an asymmetric relationship where the supplier can change customers easily while the buyer is completely reliant on the supplier due to the difficulty and cost of finding and changing supply sources; (2) the captive supplier (low buyer investments and high supplier investments), in which the supplier makes investments to gain and keep the customer; (3) a market exchange (low investments by buyer and supplier), where both buyer and supplier can find another partner in the market and change at low cost and minimal damage and (4), the strategic partnership (high specific investments by buyer and supplier), in which buyer and supplier bring their own high value assets to the relationship. Note that while the approach by McDonald takes the buyer's point of view, Bensaou's classification considers the conditions for both buyer and supplier. However, Tang (1999) claimed that it is not only the bargaining power that plays an important role but also the strategic importance of the item to be bought. Consequently, by considering these two factors he classified the supplier relationships into the following four types: (1) Vendor, a supplier who makes common parts and competes on unit price, with a low level of communication between buyer and suppliers; (2), Preferred Supplier, who tends to provide more complex/unique products. The switching cost for the buyer would be high. (3) Exclusive supplier, who tends to provide a unique product that very few suppliers can offer. The switching cost would be high for the buyer. (4) Partner, a supplier who provides unique products and commits to revenue and risk sharing with the buyer. The buyer and supplier exchange improvement ideas and solve problems as a team, forming a strategic alliance which benefits both parties. Later, Cox (2001), proposed the Power Matrix in which he also considers four types for the buyer-supplier relationship: independence, buyer dominance, interdependence and supplier dominance.

Another approach in addressing BSR is with purchasing portfolio models. The main reference for this approach is Kraljic (1983), who proposed the purchasing portfolio matrix (PPM) to classify and manage purchases according to the profit impact and the supply risk. According to the author, buyers have to exploit their power for leverage items (high profit, low supply risk), form strategic partnerships for strategic items (high profit, high supply risk), supplier control for bottleneck items (low profit, high supply risk) and to have efficient purchasing processes for non-critical items (low profit, low supply risk). Olsen and Ellram (1997), extended the scope of Kraljic's dimensions by integrating the purchased goods' criticality (using Kraljic's matrix) with the difficulty of managing the purchase situation. The authors proposed, for the leverage category, to establish a good buyer-supplier relationship in order to create mutual respect, which could be handled, for instance, through system contracting. For the non-critical category, they proposed keeping the supplier relationship simple. However, a close relationship with the supplier is recommended for the strategic category. Finally, for the bottleneck category the authors proposed trying to 
standardise the purchases or to find substitutes. Formentini, Ellram, Boem and Da Re (2019) combined Kraljic's matrix, Olsen and Ellram's matrix and Scott and Westbrook's (Scott \& Westbrook, 1991) portfolio approach for the strategic segmentation of suppliers and the characterization of the buyer-supplier relationships. Drake, Lee and Hussain (2013) proposed a portfolio model to allocate the supply options by classifying the components according to their level of necessity for leanness (combined impact on cost and quality) and their need for agility (combined impact on time and flexibility). On the other hand, Saccani and Perona (2007) proposed four types of buyer-supplier relationship (project-based partnerships, traditional relationships, evolved partnerships and operational relationships) by considering the operational impact (volume, frequency and the running cost of the exchange) and exchange criticality (level of customization and complexity of the part, its impact on the product performance and differentiation and the risk of the supply and demand market), as the two dimensions of their contingency model. Later, Rezaei and Ortt (2012) proposed the Supplier Potential Matrix (SPM) to segment suppliers according to their willingness (confidence, commitment and motivation to engage in a long-term relationship) and their capabilities (skills and accumulated knowledge that enable them to coordinate activities and make use of their assets). Cox (2015), found the PPM matrix (Kraljic, 1983) neither fully rigorous analytically nor fully robust in its recommendations, proposing an alternative approach that combines criticality of supply (four dimensions instead of the two proposed in PPM) with the Power Matrix (Cox, 2001). Recently, Rezaei and Fallah Lajimi (2019) proposed mixing the PPM and the SPM in order to segment suppliers by considering the characteristics of the item (with PPM approach), the characteristics of the suppliers and the characteristics of the relationship (with SPM approach), proposing strategies to manage them.

After this review, Tang's classification (Tang, 1999) was found to be the most suitable for our objective to provide guidelines to buyers for setting the sourcing strategy for each item, since buyers need to examine both the bargaining power of the company and the strategic importance of the item, which are the two factors considered in this classification. Accordingly, the types of buyer-supplier relationship considered in the second dimension of the framework are: Vendor, Preferred Supplier, Exclusive Supplier and Partner.

\subsection{Third Dimension: Where Will the Item Be Made?}

The last dimension to consider is the location of supply, i.e., where to produce or whether to outsource locally or in a foreign country. When offshoring production (i.e., manufacturing a product or component in another country and importing it to the home market), there may be significant differences from the company's own country: geographical location, duties, tax structure, currency, and labour costs, among others. According to Roza, Van den Bosch and Volberda (2011), this allows firms to decrease costs in their domestic locations and also gain access to qualified personnel and potential customers in offshore locations for geographical expansion. Sometimes, offshoring production also allows entry barriers to local overseas markets to be avoided (Lee, 1986).

Kamann and Van Nieulande (2010) developed a four-step method for estimating the best geographical area for supply, based on the characteristics of the product and processes. Zeng (2000) summarised the main reasons for global sourcing and the main obstacles to the success of international sourcing, whereas Dolgui and Proth (2013) reviewed the advantages and disadvantages of offshore outsourcing.

\subsection{Overview of Alternatives for Defining a Strategic Sourcing Option}

The alternatives for each dimension are summarised in Figure 1. Each alternative must be combined with those of the other two dimensions to define a strategic sourcing option, but not all combinations are possible. For instance, the make option does not require selecting an option from the second dimension. On the other hand, in some cases the selection of an alternative for a dimension could lead to the adoption of more than one alternative for another dimension (e.g., if multiple sourcing is selected, then some suppliers can be in the local market and others offshore).

Each strategic sourcing alternative must be evaluated by considering the relevant criteria. But the evaluation depends on the characteristics of the specific situation, which we call here the relevant factors. Despite not being possible to establish the optimal sourcing strategy related to different situations, due to the different casuistry and the number of relevant factors to consider, the evaluation of options related to the value of some factors allows, in 
some cases, a number of options to be discarded from the outset. For example, there is a broad consensus that making in-house is part of the company's core competencies and helps maintain its competitive advantage (see, for example, Dolgui \& Proth, 2013; Kumar, Zampogna \& Nansen, 2010; Westphal \& Sohal, 2013). Thus, if producing an item is part of the core competency (i.e. specific know-how), outsourcing would not be an advisable option. Another example is the location of the potential suppliers; if they are offshore (depending on the country), a proper risk assessment can lead to the outsourcing option being discarded (Holweg, Reichhart \& Hong 2011). In any case, choosing and defining the best sourcing option requires collecting and analysing the information and data on the relevant factors of each situation.

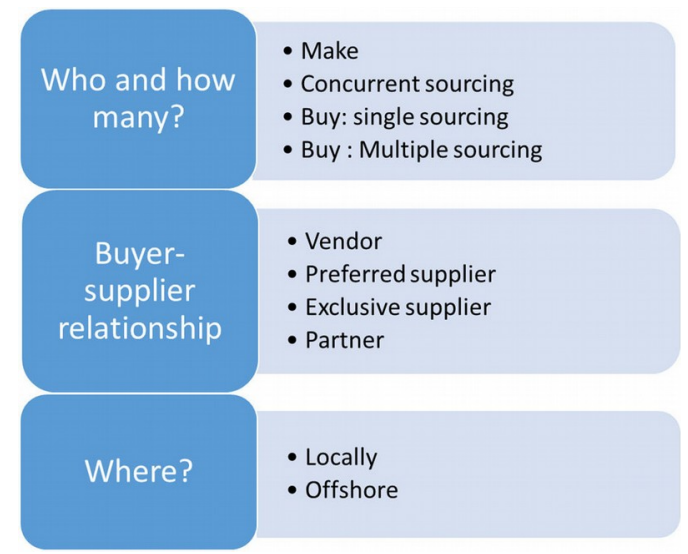

Figure 1. Alternatives for each dimension

\section{Evaluation Criteria}

The literature proposes several criteria for assessing and deciding from different sourcing options. The list of the most relevant criteria depends on the company's objectives and on the specifics of the situation.

According to Yao, Jiang, Young and Talluri (2010) cost is the main criteria when deciding whether to make an item in-house or to outsource it. Medina Serrano et al. (2018) also found in their review that the most significant criteria were cost, strategy and capabilities. However, other authors (Cox, 1999; Rafati \& Poels, 2016) criticised that all too often cost seems to be the only criterion that is considered, emphasizing the importance of a strategic vision that considers value creation through innovation, quality improvement and building long-term cooperation relationships.

Another frequently mentioned driver in the literature is a focus on the company's own core competency (e.g., Medina-Serrano et al., 2020; Westphal \& Sohal, 2013). Yao et al. (2010) suggested also considering the use of up-to-date technology, quality, and productivity.

The cost and risk of supply are the usual criteria for deciding upon the number of suppliers and their characteristics. Trevelen and Bergman Schweikhart (1988) proposed five risk-benefit categories (risks of disruption to supply and price increases, on the one hand, and benefits to inventory levels, scheduling coordination, access to technology and to quality on the other), which should be used when comparing single and multiple sourcing. Other criteria, such as the opportunities for product development, are especially relevant, particularly for deciding on the kind of relationship as opposed to the number of suppliers (Dubois \& Fredriksson 2008).

Finally, regarding the location (whether producing or outsourcing offshore), Holweg, Reichhart and Hong (2011) provide a list of rationale for global sourcing, which they based on the papers by Monczka and Giunipero (1984), Monczka and Trent (1991) and Nassimbeni (2006). The most important item on their list is the cost (which can usually be reduced due to lower prices). However, Jia, Orzes, Sartor and Nassimbeni (2017) claim that companies should consider the total cost rather than the simple purchasing cost. Other interesting criteria are, for example: reliability, quality, lead time, whether to establish a presence in a foreign market and the advantages of a more favourable taxation system. Kumar et al. (2010) highlighted the importance of considering hidden costs, such as lead times, shipping, currency fluctuations, quality, and other overheads. Johnson, Sawaya and Natarajarathinam 
(2013) presented a methodology for modelling comprehensive international procurement costs, which was based on the literature (Degraeve, Labro \& Roodhooft, 2005; Dewhurst \& Meeker, 2004; Holweg et al., 2011; Kumar \& Kopitzke, 2008; Schniederjans \& Zuckweiler, 2004; Smytka \& Clemens, 1993; Song, Platts \& Bance, 2007; Young, Swan, Thomchick \& Ruamsook, 2009; Zeng \& Rossetti, 2003). Their model includes the following costs: offshore manufacturing and purchasing; shipping and expedited shipping; inventory; financing (due to currency fluctuations); oversight and security; and taxes, tariffs and duties.

Regarding the social and ethical criteria for deciding on offshore outsourcing, Dolgui and Proth (2013) suggested considering unemployment in the countries that outsource; the transfer of core competencies from developed countries to developing countries and keeping employees at low living standards in vendor countries. They question whether it is "honest" to take advantage of a country's low social level to make employees work for ridiculously low wages. They also question whether a country has "integrity" when it uses its exchange rate to increase its competitiveness.

Table 1 summarises the criteria cited in the academic literature, which appear to be most relevant when selecting and determining a sourcing option.

\begin{tabular}{|c|c|c|}
\hline Criteria & Subcriteria & References \\
\hline \multirow{10}{*}{ Cost } & Manufacturing/purchasing & \multirow{10}{*}{$\begin{array}{l}\text { Degraeve et al. (2005), Dewhurst \& Meeker (2004), } \\
\text { Dolgui \& Proth (2013), Holweg et al. (2011), Johnson } \\
\text { et al. (2013), Kamann \& Van Nieulande (2010), } \\
\text { Kumar \& Kopitzke (2008), Kumar et al. (2010), } \\
\text { Schniederjans \& Zuckweiler (2004), Smytka \& } \\
\text { Clemens (1993), Song et al. (2007), Treleven \& } \\
\text { Bergman Schweikhart (1988), Yao et al. (2010), Young } \\
\text { et al. (2009), Zeng \& Rossetti (2003) }\end{array}$} \\
\hline & Shipping and expedited shipping & \\
\hline & Inventory & \\
\hline & Financing (currency fluctuations) & \\
\hline & Oversight and security & \\
\hline & Taxes, tariffs, and duties & \\
\hline & Quality control and lower quality & \\
\hline & Communication & \\
\hline & Lost sales & \\
\hline & Coordination & \\
\hline Keep core competencies & & Westphal \& Sohal (2013), Yao et al. (2010) \\
\hline Improve core competencies & & Westphal \& Sohal (2013), Yao et al. (2010) \\
\hline Use up-to-date technology & & Trevelen \& Schweikhart (1988), Yao et al. (2010) \\
\hline Quality & & $\begin{array}{l}\text { Holweg et al. (2011), Trevelen \& Schweikhart (1988), } \\
\text { Yao et al. (2010) }\end{array}$ \\
\hline Lead time & & Holweg et al. (2011) \\
\hline Product development & & Dubois \& Fredriksson (2008) \\
\hline Social and ethical & & Dolgui \& Proth (2013) \\
\hline \multirow{4}{*}{ Risk } & Risk of disruption of supply & Trevelen \& Schweikhart (1988) \\
\hline & Risk of price/cost increasing & Holweg et al. (2011), Trevelen \& Schweikhart (1988) \\
\hline & Intellectual property protection & Holweg et al. (2011), Kumar et al. (2010) \\
\hline & Political risk & Dolgui \& Proth (2013), Holweg et al. (2011) \\
\hline
\end{tabular}

Table 1. Main criteria to consider when assessing strategic sourcing options 


\section{Relevant Factors}

Next, we review the most relevant factors for guiding the strategic sourcing decision. These factors, which provide information about the characteristics of the situation, have been classified into three categories, which we name Context, Demand, and Product.

The Context category includes both the vendor's and potential suppliers' characteristics. On the vendor's side, the company's objectives should be considered; for example, if the company wants to open a new market in a foreign country, it may consider outsourcing the production there. In fact, Jia, Orzes, Sartor and Nassimbeni (2017), highlighted in their literature review that cost, access to the sales markets and access to resources are the main strategic goals when deciding the location. However, if the company wants to offer personalised products with short lead times, then offshoring production would probably not be an advisable option. Also, the capability, capacity, and quality that are available in-house are important factors when considering the outsourcing option (Jennings 2002; Kumar et al. 2010). The company's potential power over suppliers must also be considered: having only one supplier may lead to high dependency on them, which incurs the risk of a supplier increasing the price. However, this would probably not happen if the company had greater power (for example, when the buyer has other rapidly available supply alternatives, or if the supplier depends mostly - or even exclusively - on income from the buyer). Therefore, the number of suppliers available to provide the item is another factor to consider. Gelderman and Semeijn (2006) also consider the number of suppliers as one of the dimensions for categorizing the products. Cox, $(2015,2001,1999)$ and Rafati and Poels (2016) attach great importance to the concepts of power and dominance. Kraljic (1983) and particularly Cox (2001) provided detailed directions on how to evaluate power relationships between buyers and suppliers. Moreover, the company's managing and production system can also impact the decision. For example, regarding the number of suppliers, Sajadieh and Thorstenson (2014) emphasised that concepts such as Just-in-Time, Lean Manufacturing, and Total Quality Management often suggest reducing the number of suppliers and building long-term relationships with important suppliers.

On the supplier's side, the analysis of potential suppliers (whether local or offshore) must take into account a number of factors: their capability, capacity, communications systems, intellectual property concerns, the possibility of the supplier becoming a competitor, quality, lead time and the effect of lead time on inventory (Kumar et al., 2010). However, if the potential vendor is offshore, the country's economy, currency, political situation, and security risks must also be considered.

To sum up, the characteristics of available and potential suppliers must include the necessary technical capabilities, production capacity (including, if necessary, flexibility in adapting to changes in demand volume or product design), location (either local or offshore), the risk of suppliers becoming competitors, and other potential supply risks (such as political or economic issues).

Regarding Demand, the main characteristics to be considered are location (local and/or offshore), volume, and uncertainty. According to (Kumar et al., 2010) uncertainty increases the costs of outsourcing, especially if the products are sourced from a single vendor or if a short lead-time is required.

Finally, some relevant Product factors from those mentioned in Calleja, Corominas, Martínez-Costa and de la Torre (2018) are: complexity, the length of the cycle time and the cycle-time stage of the product. Novak and Eppinger (2001) used empirical evidence from the automobile industry to adopt a more analytical point of view of the connection between product complexity and vertical integration. They consider product complexity as having three facets: the number of components; the extent of their interactions and the degree of product novelty. They conclude that "there are benefits to concentrating production of complex systems in-house and to outsourcing simpler systems". Birou, Stanley, Fawcett and Magnan (1997) presented a model to align the purchasing strategies with the product life cycle from the design stage to maturity.

Table 2 summarises the main factors to consider when selecting the sourcing strategy for an item. 


\begin{tabular}{|c|c|c|c|}
\hline \multicolumn{2}{|c|}{ Categories } & Factors & References \\
\hline \multirow{12}{*}{ Context } & \multirow{6}{*}{ Company } & Presence in a foreign market (objectives) & Jennings (2002), Kumar et al. (2010) \\
\hline & & Capability & $\begin{array}{l}\text { Cánez, Platts \& Probert (2000), Kumar et al. (2010), } \\
\text { Jennings (2002), Nordigården et al. (2014) }\end{array}$ \\
\hline & & Quality in-house & Kumar et al. (2010) \\
\hline & & Capacity & Cánez et al. (2000), Kumar et al. (2010) \\
\hline & & Power over suppliers & Kumar et al. (2010) \\
\hline & & Desired lead time & Kumar et al. (2010) \\
\hline & \multirow{6}{*}{$\begin{array}{l}\text { Potential } \\
\text { suppliers }\end{array}$} & Location & Kumar et al. (2010) \\
\hline & & Capability & $\begin{array}{l}\text { Cánez et al. (2000), Kumar et al. (2010), Nordigården } \\
\text { et al. (2014) }\end{array}$ \\
\hline & & Quality & Cánez et al. (2000), Kumar et al. (2010) \\
\hline & & Capacity & Kumar et al. (2010) \\
\hline & & Number & Gelderman \& Semeijn (2006), Kraljic (1983) \\
\hline & & Flexibility to changes in demand & Jennings (2002), Kumar et al. (2010) \\
\hline \multirow{3}{*}{\multicolumn{2}{|c|}{ Demand }} & Location & Kumar et al. (2010) \\
\hline & & Uncertainty (volume) & Jennings (2002), Kumar et al. (2010) \\
\hline & & Volume & \\
\hline \multirow{3}{*}{\multicolumn{2}{|c|}{ Product }} & Core competency & $\begin{array}{l}\text { Dolgui \& Proth (2013), Kumar et al. (2010), Westphal } \\
\text { \& Sohal (2013) }\end{array}$ \\
\hline & & Complexity & Cánez et al. (2000), Howard \& Squire (2007) \\
\hline & & Life cycle & Novak \& Eppinger (2001), Calleja et al. (2018) \\
\hline
\end{tabular}

Table 2. Main factors when considering the sourcing strategy for an item

\section{Process for Choosing a Strategic Sourcing Option}

It is generally not possible to ascertain the best sourcing strategy for an item without assessing the existing procurement and sourcing options with the most relevant evaluation criteria, according to the specifics of the situation (relevant factors). Hence, based on the revision of the sourcing options, factors and criteria, a multi-step process (Figure 2) is recommended for deciding the sourcing strategy for an item, which is explained next.

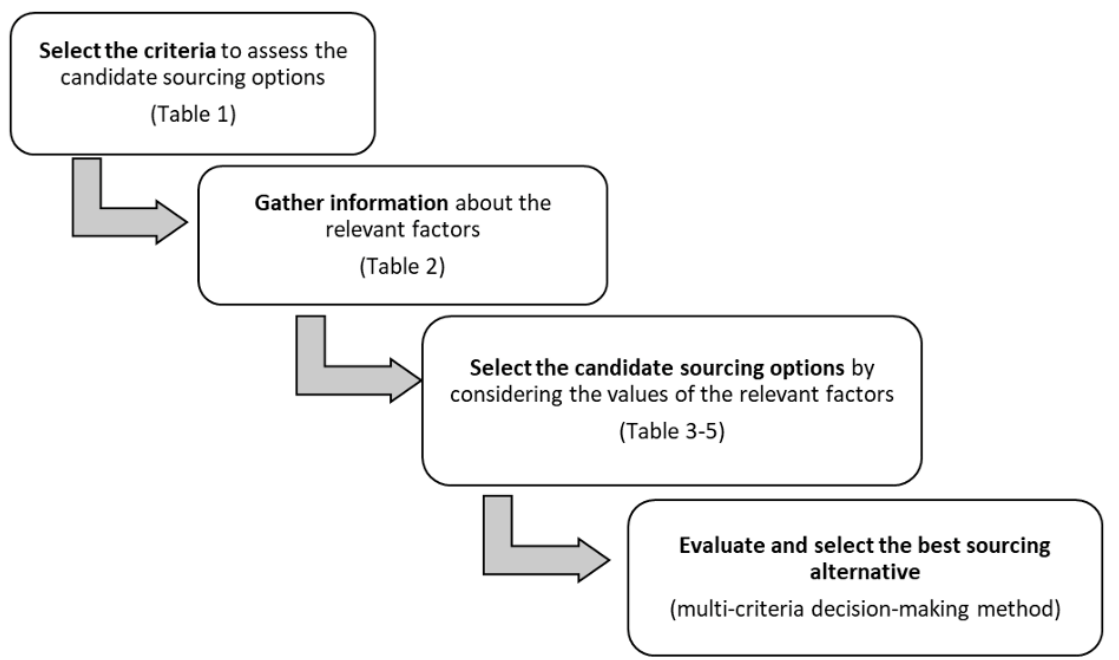

Figure 2. Flowchart of the process for choosing a strategic sourcing option 


\section{Step 1: Selection of Relevant Criteria for Assessing the Purchasing Options}

Determining the most relevant criteria will depend on the company's objectives and the specifics of the situation. For example, if the company wants to have presence in a foreign market and considers either buying or producing there to be a requirement, the cost, the quality, the lead time and the risk will be the criteria with the most important roles. In fact, quality, cost and risk are three categories of criteria to consider in most evaluations but the specific type of cost, for instance, depends on the given situation. For example, taxes, tariffs and duties are relevant when evaluating who and how many will produce the item and where it will be made; whereas the quality control costs, as well as the coordination and communication costs, are relevant when considering alternatives for the first and second dimensions (who and how many and the type of relationship, respectively).

\section{Step 2: Gather Information About the Context, Products and Demand}

This step aims to take into account the factors that could affect the selection of the strategic sourcing options. Hence, it is necessary to collect information about the items (complexity, life cycle, strategic importance for the company...), the demand (volume, uncertainty, locations...), the company (objectives, desired lead time, capacity, capability to produce the different items) and the potential suppliers (capabilities, capacity, quality, flexibility and locations). In this step it is also useful to cluster items into families to distinguish, for instance, between commodities and more specialised and unique items provided by fewer suppliers.

Perhaps not all of the factors provided in Table 2 are relevant for a given situation but this list helps to consider all factors nimbly and discard those that are not applicable. It should be noted that the process of identifying the characteristics of the context, the product and the demand is the most important part of the process to decide the strategic sourcing option for an item, because the decision-makers will discuss and agree on the importance of the different items and suppliers, as well as the alignment between the company and purchasing strategy.

\section{Step 3: Select the Best Alternatives Among the Possible Strategic Sourcing Options}

Choosing the right strategic option means selecting the best alternative for each dimension (who and how many, buyer-supplier relationship and where) as well as the importance given to each evaluation criterion, which depends on the characteristics of the problem. Therefore, for each dimension, one can evaluate if a specific option is more or less suitable for a given value of a factor.

It is worth noting that although the three dimensions are related, for the sake of clarity we will discuss the values of the relevant factors per dimension in order to aid the selection of the best alternatives.

Related to the first dimension, the company has to decide whether to make the item, simultaneously make and buy it (concurrent sourcing) or to buy the item from one or more suppliers (single or multiple sourcing).

To make is a very suitable option when the company already has the resources and the knowledge for making the item or it preserves the company's core competencies (i.e. technical advantages, know-how advantages and specialised investments (Olsen \& Ellram, 1997) and helps to maintain their competitive advantage (Kumar et al., 2010; Dolgui \& Proth, 2013; Westphal \& Sohal, 2013). This is even more the case if the quality or capacity of the potential suppliers are insufficient compared to the in-house quality. Regarding volume uncertainty, Parmigiani (2007) stated that internal sourcing is recommended when the volume uncertainty is high, in order to avoid inventory coordination problems, but also because suppliers will be less likely to invest in process improvement if they cannot guarantee the pay-back from such investments. Finally, when the production process entails complexity, either because the product itself is complex or because it is at the introduction or growth phases of its life cycle (when the process has to be adjusted and progressively improved), the company should also consider the option of making it in-house. For example, Murray, Kotabe and Wildt (1995) highlighted that manufacturers tend to choose insourcing for major components that need highly specialised assets.

But there are situations where concurrent sourcing can be more suitable. For instance, if the company wants to increase their capacity they could use outsourcing in order to complement in-house production, to optimise the capacity utilization of the owned plants, to outsource less cost-efficient production or as a tool for learning how to outsource (Nordigården et al., 2014). By keeping part of the production in-house, companies can choose the best 
option according to their needs. If the bargaining power of suppliers is high, by producing the item in-house the firm has more control over the price and the supply of components (Porter, 1980). Moreover, with concurrent sourcing they can reduce the opportunistic behaviour of suppliers and the risk when the level of demand uncertainty is high (Ju, Murray, Gao \& Kotabe, 2019), as well as when the potential suppliers do not have the flexibility to face changes in demand, as could happen in the growth phase. Ju et al. (2019) examined multinational firms' sourcing strategies in emerging economies and pointed out that non-standardised major components are best sourced using either insourcing or concurrent sourcing when there are high levels of institutional regulations. On the other hand, although concurrent sourcing allows companies to be more flexible when facing uncertainty, Parmigiani (2007) found that the quantity to be produced internally does not depend on volume uncertainty but perhaps on other aspects, such as the minimum efficient scale or demand for other products that use the same resources.

Finally, the buying option has to be considered if the company does not have the technology or the know-how, or the item is widely available from various independent suppliers and there is no important added value by making it in-house. For a standardised product in a highly competitive market, the buyer can opt for buying the product from several suppliers in order to keep the product cost low. Moreover, multiple sourcing has been seen as a response to uncertainties in the deliveries of one supplier, which can be delayed due to different contingencies (Quayle, 1998). Additionally, the allocation of orders to different suppliers encourages better performance in deliveries and quality (Carr \& Truesdale, 1992). Birou et al. (1997) highlights the need for flexibility, especially with regard to the volume of demand in the growth phase, which requires using a large number of suppliers. However, single sourcing is more suitable if producing the item means investing in specific technology or the supplier's know-how. According to Faes and Matthyssens (2009) single sourcing allows improved products and better quality due to the supplier being able to acquire more expertise in developing solutions when a problem arises. Birou et al. (1997) recommend single sourcing in the design and introduction phases, with additional focus on the procurement of more sophisticated subassemblies. But single sourcing should be discarded if none of the potential suppliers have enough capacity or enough flexibility to face changes in demand.

On the other hand, Faes and Matthyssens (2009) found that outsourcing the item to more than one supplier can mitigate the effects of uncertainty, but increases the risk of leaking secret information in the case of strategic products.

Table 3 shows the suitability of each option according the value of the relevant factors for this dimension. The different alternatives are assessed as very suitable $(++)$, suitable $(+)$, non-suitable $(-)$ or absolutely non-suitable (--). Those situations in which the value of a factor cannot determine if the option is suitable or not without considering the other factors at the same time are marked with a \pm .

If the decision taken for the first dimension is concurrent sourcing or buying, then the buyer has to consider the type of relationship with the supplier/s. As previously stated, we consider the four groups proposed by Tang (1999), which take into account both the strategic importance of the item, the extent to which it can help the buyer meet the "qualifying criteria" and "order-winning criteria" (Hill, 1993) and the buyer's bargaining power. But, apart from these two factors, there are some others, or combinations of factors, that could influence the type of relationship to establish. There follows a discussion about the relevant factors that influence the selection of each type of relationship.

The Vendor approach is suitable when the buyer is in an advantageous situation compared to the supplier. This might be because of the high volume of the purchase, its financial position, or the buyer's strong reputation in the market due to its brand, especially if the item does not have any special requirements, i.e., the strategic importance is low on the buyer's part. Normally, there are numerous suppliers in the market and the supplier switching cost (advanced technology or highly confidential know-how to give up or exchange with another supplier to start a new relationship (Morsy, 2017)) is low. This situation is typical in products in their maturity stage (products not subject to major technological innovation or design changes), or in standardised parts, where the uncertainty of demand is usually low and, probably, the potential supplier's capability (skills and knowledge of the production process) and the product quality are guaranteed. In this case, the buyer should establish a market-base, arms-length relationship 
with the supplier as there are other suppliers in the market and there is little to gain from investing in this relationship.

\begin{tabular}{|c|c|c|c|c|c|c|c|}
\hline \multicolumn{4}{|c|}{ Factors } & Make & $\begin{array}{l}\text { Concurrent } \\
\text { sourcing }\end{array}$ & $\begin{array}{l}\text { Single } \\
\text { sourcing }\end{array}$ & $\begin{array}{l}\text { Multiple } \\
\text { sourcing }\end{array}$ \\
\hline \multirow{14}{*}{ Context } & \multirow{6}{*}{ Company } & \multirow{2}{*}{ Capability } & Yes & ++ & + & \pm & \pm \\
\hline & & & No & -- & -- & + & + \\
\hline & & \multirow{2}{*}{$\begin{array}{l}\text { Quality } \\
\text { in-house }\end{array}$} & High & + & + & \pm & \pm \\
\hline & & & Low & -- & -- & + & + \\
\hline & & \multirow{2}{*}{ Capacity } & Yes & + & + & \pm & \pm \\
\hline & & & No & -- & - & + & + \\
\hline & \multirow{8}{*}{$\begin{array}{l}\text { Potential } \\
\text { supplier }\end{array}$} & \multirow{2}{*}{ Capability } & Yes & \pm & \pm & + & + \\
\hline & & & No & + & -- & -- & -- \\
\hline & & \multirow{2}{*}{ Quality } & High & \pm & \pm & + & + \\
\hline & & & Low & + & - & - & - \\
\hline & & \multirow{2}{*}{ Capacity } & Yes & \pm & \pm & + & + \\
\hline & & & No & + & + & -- & \pm \\
\hline & & \multirow{2}{*}{$\begin{array}{l}\text { Flexibility to } \\
\text { changes in demand }\end{array}$} & Yes & \pm & \pm & + & + \\
\hline & & & No & + & + & \pm & \pm \\
\hline \multirow{2}{*}{\multicolumn{2}{|c|}{ Demand }} & \multirow{2}{*}{ Uncertainty } & High & + & + & \pm & + \\
\hline & & & Low & \pm & \pm & \pm & \pm \\
\hline \multirow{7}{*}{ Product } & & \multirow{2}{*}{ Core competency } & Yes & ++ & -- & -- & -- \\
\hline & & & No & \pm & \pm & + & + \\
\hline & & \multirow{2}{*}{ Complexity } & Yes & + & \pm & + & - \\
\hline & & & No & \pm & \pm & + & + \\
\hline & & \multirow{3}{*}{ Life cycle } & Intro & + & \pm & + & - \\
\hline & & & Growth & \pm & \pm & \pm & + \\
\hline & & & Maturity & \pm & \pm & + & + \\
\hline
\end{tabular}

Table 3. Evaluation of the relevant factors to select the candidate sourcing options

The Preferred Supplier is suitable for more complex products, which are important to the buyer (Tang, 1999). Normally, there are fewer suppliers in the market and the switching cost would be higher due to the asset-specific investment. Although the buyer has some bargaining power due to having, for instance, in-house capability to produce the item, or the knowledge of how to produce it, there is a need for a cooperative and coordinated relationship. In some cases, the bargaining power comes from the high volume of the purchase (i.e. product is in its growth phase) which it tries to maintain by working with a group of suppliers. The buyer can create incentives for the supplier to reduce costs or improve quality or to be flexible to changes in demand. In this case, long-term relationships should be created with suppliers and flexibility and lead times improved, which will require the frequent exchange of information.

The Exclusive Monitoring approach is suitable when the item is unique and very few other suppliers can provide it, but it is not strategic for the buyer (Tang, 1999). In this case the bargaining power of the buyer is low if they are not important customers of the supplier, due to a low or uncertain volume of purchases. Therefore, the buyer has to guarantee the supply with long-term contracts. In this case the buyer can also create incentives for the supplier/s to improve their performance (cost, quality, punctual delivery) with long-term agreements on quality and cost. 
Finally, the Partner approach is appropriate for unique items, which are strategic to the buyer. If there are few alternative suppliers and the switching cost is high, the position of the buyer is weak. Therefore, it is better to try to develop a partnership where the supplier commits to revenue and risk sharing. In fact, relationships based on collaboration, the willingness to solve problems together and share information are the most frequent success factors in partnerships (Medina Serrano et al., 2018). The supplier can help the buyer to be more competitive in terms of cost, quality, delivery or new product introduction (Tang, 1999). McDonald (1999) pointed out that this type of relationship is suitable when it is necessary to invest in specific assets; Sajadieh and Thorstenson (2014) highlighted that concepts such as Just-in-Time, Lean Manufacturing, and Total Quality Management often suggest building long-term relationships with important suppliers. Quayle (1998) noted that end products which require specific investment may lead an organization to adopt single sourcing with long-term relationships and/or partnerships with the supplier.

\begin{tabular}{|c|c|c|c|c|c|c|c|c|c|}
\hline \multicolumn{6}{|c|}{ Factors } & Vendor & $\begin{array}{l}\text { Preferred } \\
\text { Supplier }\end{array}$ & $\begin{array}{l}\text { Exclusive } \\
\text { Supplier }\end{array}$ & Partner \\
\hline \multirow{8}{*}{ Context } & \multirow{4}{*}{ Company } & \multirow{2}{*}{ Power over suppliers } & High & & & ++ & + & + & - \\
\hline & & & Low & & & \pm & \pm & ++ & ++ \\
\hline & & \multirow{2}{*}{ Desired lead time } & High & & & \pm & \pm & \pm & \pm \\
\hline & & & Low & & & \pm & + & + & + \\
\hline & \multirow{4}{*}{$\begin{array}{l}\text { Potential } \\
\text { Supplier }\end{array}$} & \multirow{2}{*}{ Number } & High & & & ++ & + & + & \pm \\
\hline & & & Low & & & - & + & ++ & ++ \\
\hline & & \multirow{2}{*}{$\begin{array}{l}\text { Flexibility to } \\
\text { changes in demand }\end{array}$} & Yes & & & \pm & + & + & ++ \\
\hline & & & No & & & \pm & \pm & \pm & \pm \\
\hline \multirow{4}{*}{ Demand } & & \multirow{4}{*}{ Volume } & \multirow{2}{*}{ High } & \multirow{4}{*}{ Uncertainty } & $\mathrm{H}$ & + & + & + & + \\
\hline & & & & & $\mathrm{L}$ & ++ & + & + & + \\
\hline & & & \multirow{2}{*}{ Low } & & $\mathrm{H}$ & - & + & - & - \\
\hline & & & & & $\mathrm{L}$ & - & + & + & \\
\hline \multirow{5}{*}{ Product } & & \multirow{2}{*}{ Complexity } & High & & & \pm & + & ++ & ++ \\
\hline & & & Low & & & ++ & \pm & \pm & \pm \\
\hline & & \multirow{3}{*}{ Life cycle } & Intro & & & \pm & + & ++ & ++ \\
\hline & & & Growth & & & \pm & + & + & + \\
\hline & & & Maturity & & & ++ & + & \pm & \pm \\
\hline
\end{tabular}

Table 4. Evaluation of the relevant factors in selecting the buyer-supplier relationship

Table 4 shows the suitability of each type of relationship, according to the value of each factor, in spite of the fact that in most cases the decision has to be taken by considering the combination of different factors. For instance, a high acceptable lead time does not determine the type of relationship but, if it is low, it is probably better to have a stronger relationship than that provided by the Vendor approach, hence a + is put in the cells from the Preferred Supplier to Partner. However, other factors should be considered when deciding which of these is more convenient, such as the buyer's power over the supplier and the type of item to buy.

Finally, the third dimension aims to decide whether to make or buy the item locally or in a foreign country. In this case, one of the main factors to consider is the need to have presence in a foreign market if producing or buying there provides some advantage (lower taxes, cost, reduced lead time, low barriers to enter the market...). If the location of demand is local and the item is complex, it might be better to make/buy locally to ensure the quality and lead time. Conversely, for standard products with a high volume and low uncertainty of demand, producing/buying the item abroad could be an option if it is cheaper (similar to what most of the fashion 
companies do with basic clothes). However, when the uncertainty of demand is high (for instance, for those items which are in the introduction phase), cost is often secondary to responsiveness. Therefore, it is necessary to consider the response time when deciding on the location. Finally, Holweg et al. (2011) highlighted the incompatibility of just-in-time with global sourcing due to the lack of buyer-supplier proximity when frequent deliveries are needed. Table 5 evaluates the suitability of sourcing locally or offshore, according to the value of the relevant factors for this dimension.

\begin{tabular}{|c|c|c|c|c|c|}
\hline \multicolumn{3}{|r|}{ Factors } & & Locally & Offshore \\
\hline \multirow{5}{*}{ Context } & \multirow{3}{*}{ Company } & Presence in a foreign market (objectives) & & \pm & ++ \\
\hline & & \multirow{2}{*}{ Short lead time } & Yes & ++ & \pm \\
\hline & & & No & \pm & \pm \\
\hline & \multirow{2}{*}{ Potential Supplier } & \multirow{2}{*}{ Location } & Local & + & \pm \\
\hline & & & Desired market & \pm & + \\
\hline \multirow{2}{*}{\multicolumn{2}{|c|}{ Demand }} & \multirow{2}{*}{ Location } & Local & + & \pm \\
\hline & & & Abroad & \pm & + \\
\hline \multirow{5}{*}{ Product } & & \multirow{2}{*}{ Complexity } & High & + & - \\
\hline & & & Low & \pm & \pm \\
\hline & & \multirow{3}{*}{ Life cycle } & Intro & ++ & - \\
\hline & & & Growth & + & + \\
\hline & & & Maturity & \pm & \pm \\
\hline
\end{tabular}

Table 5. Evaluation of the relevant factors for selecting the sourcing location

Notice that the output of this second step is a set of potentially strategic sourcing options that will be later evaluated according to given criteria.

\section{Step four. Assessing and Selecting the Purchasing Options}

Selecting the most appropriate strategic sourcing option from the ones that have been retained in step 3 constitutes a multi-criteria decision problem, in which the strategic sourcing options to consider are those retained in step 3; the evaluation criteria (both qualitative and quantitative) are the most relevant ones selected in step 1; and for assessing each option with regard to each criterion, as much complete and detailed information as possible regarding the relevant factors (from Table 2) has to be analysed.

There are different multi-criteria decision making methods, more or less formalised or sophisticated, that can be used (e.g. the Weighted Average Multi-criteria, the Analytical Hierarchic Process (Saaty, 1987) or the Technique for Order Preference by Similarity to Ideal Solution (TOPSIS) method (Hwang \& Yoon 1981)). In fact, Medina-Serrano et al. (2020) combine the pairwise comparison assessment for weighting criteria with TOPSIS to help decide between Make, Buy or Plural sourcing.

\section{Conclusions and Further Research}

This paper proposes a multi-step process for selecting the most suitable strategic sourcing option for an item or item's family by considering the characteristics of the context, demand and product.

The three-dimensional approach to defining a strategic sourcing alternative (sourcing option, buyer supplier relationship and location of supply), together with a detailed revision of the relevant criteria and factors to consider during this process, are the three pillars which support the decision-making process.

The proposed process starts with the selection of a group of criteria to evaluate the sourcing option candidates, according to the company's objectives and the characteristics of the situation. Table 1 provides an inventory of the 
main criteria to consider. Then, the decision-making group has to collect information about the characteristics of the context, the demand and the item. The most relevant factors have been collected in Table 2. This information will help, in step 3, to select a set of alternative sourcing candidates according to the characteristics of the situation. The discussion, together with Tables 3-5, can help to determine the most suitable alternatives for each dimension. Finally, in step four, the best sourcing option must be chosen from the candidates obtained in the previous step. This requires a multi-criteria decision-making method which takes into account the criteria previously selected in the first step.

\section{Managerial Implications}

Our research shows that the decisions involved in the design of the procurement and production network of a supply chain go beyond the options of make or buy. Defining the strategic sourcing options requires considering two more dimensions concerning, respectively, the kind of relationship between the buyer and supplier(s) and the country where the item is to be made. Moreover, each family of items regarding the obtention and distribution of the product, as well as its collection when used, requires different decisions.

We think that our analysis of the three dimensions considered may help decision-makers to define the feasible strategic sourcing options available for each family of items. Additionally, the discussion of the relevant factors and criteria provides significant material for evaluating the options.

\section{Limitations and Future Research}

There are some limitations in this study that call for further research. Firstly, most of the reviewed papers dealt with sourcing in manufacturing industries, which could hide some specific criteria or factors considered in services. Next, the methodology has been presented from a theoretical point of view. Therefore, the application of this methodology by companies from different sectors would be interesting, to illustrate its use as well as the main challenges considered in each step. Finally, we identify the main factors and criteria mentioned in the literature review but this list can be extended with new case studies.

Future research should also focus on developing tools that support, first of all, the selection of the relevant criteria for each particular strategic sourcing option and, secondly, allow evaluating options while considering the pertinent factors. Another potential line of research would be to develop specific multiple-criteria decision-making methods and tools for selecting the most appropriate strategic sourcing options from those discussed in this paper.

\section{Declaration of Conflicting Interests}

The authors declared no potential conflicts of interest with respect to the research, authorship, and/or publication of this article.

\section{Funding}

This work was supported by the Ministerio de Economía y Competitividad / FEDER [DPI2015-67740-P].

\section{References}

Bensaou, M. (1999). Portfolios of Buyer-Supplier Relationships. Sloan Management Review, 40(4), 35-44.

Birou, L., Stanley, E., Fawcett, S.E., \& Magnan, G.M. (1997). Integrating Product Life Cycle and Purchasing Strategies. International Journal of Purchasing and Materials Management, 33(4), 23-31. https://doi.org/10.1111/j.1745493X.1997.tb00022.x

Calleja, G., Corominas, A., Martínez-Costa, C., \& de la Torre, R. (2017). Methodological Approaches to Supply Chain Design. International Journal of Production Research, 7543(December), 1-23.

Cánez, L.E., Platts, K.W., \& Probert, D.R. (2000). Developing a Framework for Make-or-buy Decisions. International Journal of Operations \& Production Management, 20(11), 1313-1330. https://doi.org/10.1108/01443570010348271 
Carr, C.H., \& Truesdale, T.A. (1992). Lessons from Nissan's British Suppliers. International Journal of Operations \& Production Management, 12(2), 49-57. https://doi.org/10.1108/01443579210009050

Corominas, A., Mateo, M., Ribas, I., \& Rubio, S. (2015). Methodological Elements of Supply Chain Design. International Journal of Production Research, 53(16). https://doi.org/10.1080/00207543.2015.1013641

Cox, A. (1999). Power, Value and Supply Chain Management. Supply Chain Management: An International Journal, 4(4), 167-175. https://doi.org/10.1108/13598549910284480

Cox, A. (2001). Understanding Buyer and Supplier Power: A Framework for Procurement and Supply Competence. Journal of Supply Chain Management, 37(2), 8. https://doi.org/10.1111/j.1745-493X.2001.tb00094.x

Cox, A. (2015). Sourcing Portfolio Analysis and Power Positioning: Towards a 'Paradigm Shift' in Category Management and Strategic Sourcing. Supply Chain Management: An International Journal, 20(6), 717-736. https://doi.org/10.1108/SCM-06-2015-0226

Degraeve, Z., Labro, E., \& Roodhooft, F. (2005). Constructing a Total Cost of Ownership Supplier Selection Methodology Based on Activity-Based Costing and Mathematical Programming. Accounting and Business Research, 35(1), 3-27. https://doi.org/10.1080/00014788.2005.9729660

Dewhurst, N.P., \& Meeker, D.G. (2004). Improved Product Design Practices Would Make U.S. Manufacturing More Cost Effective: A Case to Consider Before Outsourcing to China.

Dolgui, A., \& Proth, J.M. (2013). Outsourcing: Definitions and Analysis. International Journal of Production Research, 51(23-24), 6769-6777. https://doi.org/10.1080/00207543.2013.855338

Drake, P.R., Lee, D.M., \& Hussain, M. (2013). The Lean and Agile Purchasing Portfolio Model. Supply Chain Management: An International Journal, 18(1), 3-20. https://doi.org/10.1108/13598541311293140

Dubois, A., \& Fredriksson, P. (2008). Cooperating and Competing in Supply Networks: Making Sense of a Triadic Sourcing Strategy. Journal of Purchasing and Supply Management, 14(3), 170-179.

https://doi.org/10.1016/j.pursup.2008.05.002

Dyer, J.H., Cho, D.S., \& Cgu, W. (1998). Strategic Supplier Segmentation: The Next 'Best Practice' in Supply Chain Management. California Management Review, 40(2), 57-77. https://doi.org/10.2307/41165933

Faes, W., \& Matthyssens, P. (2009). Insights into the Process of Changing Sourcing Strategies. Journal of Business and Industrial Marketing, 24(3-4), 245-255. https:/ / doi.org/10.1108/08858620910939796

Formentini, M., Ellram, L.M., Boem, M., \& Da Re, G. (2019). Finding True North: Design and Implementation of a Strategic Sourcing Framework. Industrial Marketing Management, 77(September 2018), 182-197.

https://doi.org/10.1016/j.indmarman.2018.09.006

Gelderman, C.J., \& Semeijn, J. (2006). Managing the Global Supply Base through Purchasing Portfolio Management. Journal of Purchasing and Supply Management, 12(4), 209-217. https://doi.org/10.1016/j.pursup.2006.10.002

Giunipero, L.C., Bittner, S., Shanks, I., \& Cho, M.H. (2019). Analyzing the Sourcing Literature: Over Two Decades of Research. Journal of Purchasing and Supply Management, 25(5), 100521. https://doi.org/10.1016/j.pursup.2018.11.001

Heese, H.S. (2015). Single versus Multiple Sourcing and the Evolution of Bargaining Positions. Omega (United Kingdom), 54, 125-133. https://doi.org/10.1016/j.omega.2015.01.016

Hill, T. (1993). Manufacturing Strategy: The Strategic Management of the Manufacturing Function. London: Macmillan.

Holweg, M., Reichhart, A., \& Hong, E. (2011). On Risk and Cost in Global Sourcing. International Journal of Production Economics, 131(1), 333-341. https://doi.org/10.1016/j.ijpe.2010.04.003

Howard, M., \& Squire, B. (2007). Modularization and the Impact on Supply Relationships. International Journal of Operations and Production Management, 27(11), 1192-1212. https:/ / doi.org/10.1108/01443570710830593 
Hwang, C.L., \& Yoon, K. (1981). Multiple Attribute Decision Making (186). Berlin, Heidelberg: Springer Berlin Heidelberg. https://doi.org/10.1007/978-3-642-48318-9

Jennings, D. (2002). Strategic Sourcing: Benefits, Problems and a Contextual Model. Management Decision, 40(1), $26-34$. https://doi.org/10.1108/00251740210413334

Jia, F., Orzes, G., Sartor, M., \& Nassimbeni, G. (2017). Global Sourcing Strategy and Structure: Towards a Conceptual Framework. International Journal of Operations and Production Management, 37(7), 840-864. https://doi.org/10.1108/IJOPM-09-2015-0549

Johnson, M.D., Sawaya, W.J., \& Natarajarathinam, M. (2013). A Methodology for Modelling Comprehensive International Procurement Costs. International Journal of Production Research, 51(18), 5549-5564. https://doi.org/10.1080/00207543.2013.787170

Ju, M., Murray, J.Y., Gao, G.Y., \& Kotabe, M. (2019). Concurrent Sourcing Strategy of Multinational Firms in China: Drivers and Performance Implications. Journal of World Business, 54(6). https://doi.org/10.1016/j.jwb.2019.101015

Kamann, D., \& Van Nieulande, V. (2010). A Four-Filter Method for Outsourcing to Low-Cost Countries. Journal of Supply Chain Management, 46(2), 64-79. https://doi.org/10.1111/j.1745-493X.2010.03190.x

Kraljic, P. (1983). Purchasing Must Become Supply Management. Harvard Business Review, 61(5),109-117.

Kumar, S., \& Kopitzke, K.K. (2008). A Pactitioner's Decision Model for the Total Cost of Outsourcing and Application to China, Mexico, and the United States. Journal of Business Logistics, 29(2), 107-139. https://doi.org/10.1002/j.2158-1592.2008.tb00089.x

Kumar, S., Zampogna, P., \& Nansen, J. (2010). A Closed Loop Outsourcing Decision Model for Developing Effective Manufacturing Strategy. International Journal of Production Research, 48(7), 1873-1900. https://doi.org/10.1080/00207540802680542

Lee, J. (1986). Determinants of Offshore Production in Developing Countries. Journal of Development Economics, 20(1), 1-13. https://doi.org/10.1016/0304-3878(86)90002-7

Matthyssens, P., \& Faes, W. (1996). The Effectiveness of Parallel and Single Sourcing: Purchasing and Marketing Implications. In Gemünden, H.G., Ritter, T., \& Walter, A. (Eds.), IMP Conference (12th): Interaction, Relationships And Networks (1001-1010). Karlsruhe, Germany.

McDonald, F. (1999). The Importance of Power in Partnership Relationships. Journal of General Management, 25(1), 43-59. https://doi.org/10.1177/030630709902500103

Medina-Serrano, R., González-Ramírez, R., Gascó, J.L., \& Llopis, J. (2020). Strategic Sourcing: Developing a Progressive Framework for Make-or-Buy Decisions. Journal of Industrial Engineering and Management, 13(1), $133-54$. https://doi.org/10.3926/jiem.2858

Medina-Serrano, R., González-Ramírez, R., \& Gascó, J.L. (2018). Should We Make or Buy? An Update and Review. European Research on Management and Business Economics, 24(3), 137-148. https://doi.org/10.1016/j.iedeen.2018.05.004

Monczka, R.M., \& Giunipero, L.C. (1984). International Purchasing: Characteristics and Implementation. Journal of Purchasing and Materials Management, 20(3), 2-9. https://doi.org/10.1111/j.1745-493X.1984.tb00107.x

Monczka, R.M., \& Trent, R.J. (1991). Global Sourcing: A Development Approach. International Journal of Purchasing and Materials Management, 27(2), 2-8. https:/ / doi.org/10.1111/j.1745-493X.1991.tb00527.x

Morsy, H. (2017). Buyer-Supplier Relationships and Power Position: Interchaining. International Journal of Supply and Operations Management VO, 44(1), 43.

Murray, J.Y., Kotabe, M., \& Wildt, A.R. (1995). Strategic and Financial Performance Implications of Global Sourcing Strategy: A Contingency Analysis. Journal of International Business Studies, 26(1), 181-202. https://doi.org/10.1057/palgrave.jibs.8490171 
Najafi, N., Lind, F., \& Pedersen, A.C. (2014). Changing Sourcing Strategies to Make the Most of Them. IMP Conference.

Nassimbeni, G. (2006). International Sourcing: Empirical Evidence from a Sample of Italian Firms. International Journal of Production Economics, 103(2), 694-706. https://doi.org/10.1016/j.ijpe.2006.01.003

Nordigården, D., Rehme, J., Brege, S., Chicksand, D., \& Walker, H. (2014). Outsourcing Decisions - the Case of Parallel Production. International Journal of Operations and Production Management, 34(8), 974-1002.

https://doi.org/10.1108/IJOPM-06-2012-0230

Novak, S., \& Eppinger, S.D. (2001). Sourcing by Design: Product Complexity and the Supply Chain. Management Science, 47(1), 189-204. https://doi.org/10.1287/mnsc.47.1.189.10662

Olsen, R.F., \& Ellram, L.M. (1997). A Portfolio Approach to Supplier Relationships. Industrial Marketing Management. https://doi.org/10.1016/S0019-8501(96)00089-2

Parmigiani, A. (2007). Why Do Firms Both Make and Buy? An Investigation of Concurrent Sourcing. Strategic Management Journal, 28, 285-311. https://doi.org/10.1002/smj.580

Parmigiani, A., \& Mitchell, W. (2009). Complementary, Capabilities, and Boundaries of the Firm: The Impact of within-Firm and Interfirm Expertise on Concurrent Sourcing of Complementary Components. Strategic Management Journal, 30, 1065-1091. https://doi.org/10.1002/smj.769

Porter, M.E. (1980). Competitive Strategy: Techniques for Analyzing Industries and Competitors. New York: Free Press.

Quayle, M. (1998). Industrial Procurement: Factors Affecting Sourcing Decisions. European Journal of Purchasing and Supply Management, 4(4), 199-205. https:// doi.org/10.1016/S0969-7012(98)00011-2

Rafati, L., \& Poels, G. (2016). Service-Dominant Strategic Sourcing: Value Creation versus Cost Saving. In Lecture Notes in Business Information Processing (247, 30-44). Springer Verlag. https://doi.org/10.1007/978-3-319-32689-4_3

Rezaei, J., \& Fallah Lajimi, H. (2019). Segmenting Supplies and Suppliers: Bringing Together the Purchasing Portfolio Matrix and the Supplier Potential Matrix. International Journal of Logistics Research and Applications, 22(4), 419-436. https://doi.org/10.1080/13675567.2018.1535649

Rezaei, J., \& Ortt, R. (2012). A Multi-Variable Approach to Supplier Segmentation. International Journal of Production Research, 50(16), 4593-4611. https://doi.org/10.1080/00207543.2011.615352

Richardson, J. (1993). Parallel Sourcing and Supplier Performance in the Japanese Automobile Industry. Strategic Management Journal, 14(5), 339-350. https://doi.org/10.1002/smj.4250140503

Roza, M., Van den Bosch, F.A., \& Volberda, H.W. (2011). Offshoring Strategy: Motives, Functions, Locations, and Governance Modes of Small, Medium-Sized and Large Firms. International Business Review, 20(3), 314-323. https://doi.org/10.1016/j.ibusrev.2011.02.002

Saaty, R.W. (1987). The Analytic Hierarchy Process-What It Is and How It Is Used. Mathematical Modelling, 9(3-5), 161-176. https://doi.org/10.1016/0270-0255(87)90473-8

Saccani, N., \& Perona, M. (2007). Shaping Buyer-Supplier Relationships in Manufacturing Contexts: Design and Test of a Contingency Model. Journal of Purchasing and Supply Management, 13(1), 26-41. https://doi.org/10.1016/j.pursup.2007.03.003

Sajadieh, M.S., \& Thorstenson, A. (2014). Comparing Sourcing Strategies in Two-Echelon Supply Chains. Computers and Operations Research, 45, 108-115. https://doi.org/10.1016/j.cor.2013.12.006

Schniederjans, M.J., \& Zuckweiler, K.M. (2004). A Quantitative Approach to the Outsourcing-Insourcing Decision in an International Context. Management Decision, 42(8), 974-986. https://doi.org/10.1108/00251740410555461

Scott, C., \& Westbrook, R. (1991). New Strategic Tools for Supply Chain Management. International Journal of Physical Distribution \& Logistics Management, 21(1), 23-33. https:/ / doi.org/10.1108/09600039110002225 
Smytka, D.L., \& Clemens, M.W. (1993). Total Cost Supplier Selection Model: A Case Study. International Journal of Purchasing and Materials Management, 29(4), 42-49. https://doi.org/10.1111/j.1745-493X.1993.tb00260.x

Song, N., Platts, K., \& Bance, D. (2007). Total Acquisition Cost of Overseas Outsourcing/Sourcing: A Framework and a Case Study. Journal of Manufacturing Technology Management, 18(7), 858-875.

https://doi.org/10.1108/17410380710817291

Tang, C.S. (1999). Supplier Relationship Map. International Journal of Logistics Research and Applications, 2(1), 39-56. https://doi.org/10.1080/13675569908901571

Tangpong, C., Michalisin, M.D., Traub, R.D., \& Melcher, A.J. (2015). A Review of Buyer-Supplier Relationship Typologies: Progress, Problems, and Future Directions. Journal of Business \& Industrial Marketing, 30(2), 153-170. https://doi.org/10.1108/JBIM-10-2012-0193

Treleven, M., \& Bergman Schweikhart, S. (1988). A Risk/Benefit Analysis of Sourcing Strategies: Single vs. Multiple Sourcing. Journal of Operations Management, 7(3-4), 93-114. https:// doi.org/10.1016/0272-6963(81)90007-3

Westphal, P., \& Sohal, A.S. (2013). No TitleTaxonomy of Outsourcing Decision Model. International Journal of Production Research, 4(4-5), 347-358. https://doi.org/10.1080/09537287.2011.648486

Yao, T., Jiang, B., Young, S.T., \& Talluri, S. (2010). Outsourcing Timing, Contract Selection, and Negotiation. International Journal of Production Research, 48(2), 305-326. https://doi.org/10.1080/00207540903174858

Young, R.R., Swan, P.F., Thomchick, E.A., \& Ruamsook, K. (2009). Extending Landed Cost Models to Improve Offshore Sourcing Decisions. International Journal of Physical Distribution and Logistics Management, 39(4), 320-335. https://doi.org/10.1108/09600030910962267

Zeng, A.Z., \& Rossetti, C. (2003). Developing a Framework for Evaluating the Logistics Costs in Global Sourcing Processes: An Implementation and Insights. International Journal of Physical Distribution and Logistics Management, 33(9), 785-803. https://doi.org/10.1108/09600030310503334

Zeng, A.Z. (2000). A Synthetic Study of Sourcing Strategies. Industrial Management \& Data Systems, 100(5), 219-226. https://doi.org/10.1108/02635570010304798

Journal of Industrial Engineering and Management, 2021 (www.jiem.org)

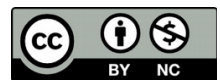

Article's contents are provided on an Attribution-Non Commercial 4.0 Creative commons International License. Readers are allowed to copy, distribute and communicate article's contents, provided the author's and Journal of Industrial Engineering and Management's names are included. It must not be used for commercial purposes. To see the complete license contents, please visit https://creativecommons.org/licenses/by-nc/4.0/. 